\title{
Translation Agencies in Iran: A Brief Investigation of the Recruitment Criteria
}

Fahime Mardani

fahim.mardani@yahoo.com

\section{Dr. Hossein Barati}

h.barati@gmail.com

\section{Dr. Akbar Hesabi}

a. hesabi11@yahoo.com

Doi:10.5901/mjss.2013.v4n2p59

\begin{abstract}
The present study reports on the findings of a questionnaire which focused on the recruitment criteria of official translation agencies. To this end, 25 managers of official translation agencies in four cities of Iran were requested to complete a questionnaire about the basic requirements for becoming a member in translation agencies. The results indicate that the most important factors according to the managers are translation competence, language competence and experience in translation. Aspects such as academic degree (B.A. or M.A.) in Translation Studies do not seem to be of high value to the managers. The findings show that graduates in Translation Studies ought to improve their skills and gain practical experience in translation. Otherwise, they will not be considered qualified enough to be the members of translation agencies. Also, the results might contribute to more considerable attention to translation practice and better translation training in universities or translation institutes.
\end{abstract}

Key words: translation agency, recruitment criteria, translation competence, Translation Studies, translation training

\section{Introduction}

Every year, hundreds of translation students graduate from universities looking for an appropriate job to satisfy their needs. Graduates in translation may wish to run their own business working as a freelancer, or apply for a job in a translation agency. In the latter case, depending on the agency, the applicants need to hold several qualifications. In other words, managers and recruiters establish a set of criteria to hire some good members in the translation agencies. These criteria may include: a university degree in translation, several years of job experience, passing a test conducted by the government or the agency, etc. However, translation agencies might consider some different criteria for selecting translators. For instance, some agencies may prioritize job experience over academic degree whereas some other may regard translation certification or academic degree as more important than translation experience. Also, famous associations or agencies usually list the qualifications for membership or certification. In his book A Practical Guide for Translators Samuelsson-Brown (2004) prepares a list of professional organizations for translators. He discusses the aims and objectives, membership benefits, and in some cases, the requirements of membership in these organizations. For instance, speaking about The Institute of Translation and Interpreting (ITI) which is located in the U.K., SamuelssonBrown provides the categories for student, associate, qualified, fellow, corporate, and subscriber membership. As a case in point, the requirements for admission to qualified membership are presented below:

1. minimum age of 25 years,

2. a first degree or postgraduate qualification in a relevant subject or a corresponding qualification accepted by the Council,

3. recommendation regarding ability, volume of work and good repute by at least two persons for translators and three for ad hoc interpreters or five for conference interpreters,

4. recent professional experience: 
a. for translators, a minimum of five years full time- considered to be in the region of 300,000 words of translation per year- or a corresponding period of part time experience- and successful assessment of work; alternatively three years' full time (or a corresponding longer period of part time) plus a pass in the ITI Membership Examination, unless the applicant can satisfy the admissions Committee that there are exceptional grounds for exception;

b. for interpreters, a minimum of two hundred days interpreting over a period of five years, or a minimum of 120 days over a period of three years plus a pass in the ITI Interpreters' Examination (p. 148-9).

The requirements listed above indicate that working as a professional translator is not as simple and straightforward as it appears to some people. Apart from a good knowledge of the second language, one needs to have some other abilities and qualifications. As Gouadec (2007) declares:

It must be emphasized from the start that the qualified professional translator is a vital player, both economically and technically: professional translators are highly skilled technical experts both on account of the contents they translate and of the various evermore sophisticated IT tools and software they must be able to use (p. xiii)

Also, addressing translator recruiters, Samuelson-Brown (2006) states:

The decision to recruit a member of staff is a major commitment and should not be taken without careful consideration. It implies responsibilities for you as an employer to provide a place of work and to ensure that training and continuous development are offered to the prospective employee. Recruiting a member of staff is a long-term commitment (p.100)

Obviously, to become a member of every association or agency of translation, translators or interpreters need to hold some educational and professional qualifications. That is, considering the fact that many people are in urgent need of appropriate translations that are supposed to fulfill their expectations, the recruiters or managers need to hire the most qualified applicants.

With regard to this issue, the present study aims to examine the qualifications that the managers of official translation agencies in Iran expect their employees to hold. Based on the purpose and the problem under focus in the present study, the following research question will be addressed:

- What principles are taken into consideration by official translation agencies in Iran for recruiting translators?

\section{Background of the Study}

Very few researches have been exclusively conducted on translation agencies and their recruitment criteria. However, in this section the researcher will attempt to provide some examples of relevant research on translation as a profession. That is, in some of these studies the main focus might not be membership of translation agencies and employment but other aspects of the profession such as the relation between the market needs and translation training.

In their books Gouadec (2007) and Samuelsson-Brown (2004) refer to some basic requirements for becoming a good translator. Discussing the prerequisites and conditions for becoming a translator, Gouadec (2007) lists the qualities that all good translators, irrespective of their background, must share:

1. absolutely perfect mastery of the languages used, and especially the target language

2. multi-cultural competence, either by upbringing or by education- 'culture' being meant here to include culture in its widest sense, but also technical culture, business culture, corporate culture, etc.

3. perfect familiarity with the domains they specialize in (either through their initial education and training, or more probably - through self-tuition;

4. an absolute knowledge of what translation means, what it requires and what it implies;

5. no interest in proving that they are better translators than the next person: they are simply interested in doing their job as professionally as possible (p. 150).

Gouadec (2007) also provides several examples to clarify the diversity of job profiles. One of the examples is presented below: 


\section{Example 1:}

Ideally you should have at least four years of translation experience.

You must speak native level English and German

Preferably some expertise in corporate governance, European law or tax.

French or Italian as second languages would be an advantage

(p. 154)

In addition, Samuelsson-Brown (2004) summarizes the desirable qualifications for becoming a translator:

- Education to university level by attaining your basic degree in modern languages or linguistics

- Spending a period in the country where the language of your choice is spoken

- Completing a postgraduate course in translation studies

- Gaining some knowledge or experience of the subjects you intend translating

- Getting a job as a trainee or junior translator with a company

- Learning to touch type

- The willingness to commit to lifelong learning (p.8)

Following two earlier studies on professional translators' views (2000) and students' opinions (2003), Li Defeng (2007) carries out a research which focuses on administrators of translation services in Hong Kong. The main concern in his study is to find ways to bring translator training closer to the real world of professional translation. In other words, his study attempts to seek what changes need to be made to improve translation training curricula. In the first part of his research, Defeng (2007) explores the primary considerations of the administrators of translation agencies in recruiting new translators. His research findings indicate that the three most important factors for administrators are the applicants' translation skill, translation/ interpretation experience and English competence. There are also several other important considerations in recruiting new translators such as the applicants' common sense, education, ability to work under pressure, the speed of translation, written Chinese, hard work and so forth. Thus, to train more competent translators, translation programs need to take all these aspects into consideration.

Chan (2009) conducts a study on the issue of translation certification and academic degree in translation. Chan's research investigates four important recruitment criteria for translation companies in Hong Kong. These are: English degree, translation certification, job experience and personal and other factors. Research findings reveal that almost all managers prefer an English degree over translation certification. Out of eight respondents, only one has preferred translation certification over an English degree. Chan concludes that the recruiters' preference for an English degree is "due to inadequate knowledge or misconceptions about the process of certification" (p.46). He argues that the managers of translation companies do not have a good understanding of translation certification and for this reason they ignore this important issue in recruitment.

Pym (2011) criticizes the university training courses that do not fulfill the market needs. He complains about the wrong method of translation classes in which the students should translate in such a way that meets with the teacher's approval (in most cases using a literal or ST-based approach). He describes these training courses unprofessional and calls for more efficient and market-oriented approaches. He also suggests some steps to be taken to bring market and translation training programs closer together.

With regard to the link between translation training programs in universities and the needs of the market, Gabr (2007) remarks: "It is imperative for translation training programs to be developed in accordance with proper assessment of three closely linked needs : the needs of the market, the needs of translation departments and -equally important- the needs of students"(p.66). Conducting a similar study, Yazdanparast (2012) has examined the link between translation market challenges and M.A. curriculum in universities. In his research he explores the practicality of translation courses in the M.A. program. To this end, the researcher solicits the view of 20 managers of translation agencies and 20 M.A. students via two separate questionnaires. The results of his study reveal that there is a big gap between translation market challenges and M.A. qualifications. In other words, the M.A. courses offered at universities of Iran, do not meet the market needs and expectations. 


\section{Methodology}

This study adopted a descriptive method of research. The researcher utilized qualitative procedures of data collection such as interviews and questionnaires. Because the study was qualitative in nature, non-parametric techniques for data analysis were employed.

\subsection{Participants}

Since the study aimed to examine the recruitment criteria of official translation agencies in Iran, the participants were selected from among the managers of translation agencies. In other words, because managers occasionally hire new members and know exactly what qualifications the employees need to have, they were considered to be the target respondents of this study. The 25 Iranian managers were requested to complete a questionnaire (see Appendix) about the required qualifications. Factors such as age and gender of the managers were not under focus in this study.

\subsection{Instruments}

In order to design a questionnaire, the researcher conducted two interviews with managers of two translation agencies in Isfahan regarding the recruitment criteria in their agencies. The interviews were recorded and then transcribed thoroughly. Following the analysis of the transcriptions, the researcher developed a five point Likert scale questionnaire of 18 items (see Appendix). This questionnaire was given to the target managers. The content and wording of the questionnaire were also examined by two expert judges in the Faculty of Foreign Languages in Isfahan University. They were professors or associate professors in the field of Translation Studies with at least 10 years of experience. For ease of data analysis, the items in the questionnaire were categorized after consultation with the above mentioned expert judges. Table 1 shows the clustered items and their specifications.

Table 1. Items and their related categories

\begin{tabular}{clc}
\hline Category Number & Specification & Items \\
\hline 1 & Academic degree in English or Translation Studies & $1,2,5$ \\
\hline 2 & Extensive knowledge of both English and Persian & 15,17 \\
\hline 3 & High level of translation competence & 3,4 \\
\hline $\mathbf{5}$ & Employment examination & $7,8,9,10$ \\
\hline $\mathbf{6}$ & Translation training & 14,18 \\
\hline $\mathbf{7}$ & Good experience in translation & 6 \\
\hline $\mathbf{8}$ & Age and gender of the applicants & 11,13 \\
\hline $\mathbf{9}$ & Computer skills & 12 \\
\hline
\end{tabular}

As Table 1 shows, the questions were made of 9 factors. Items 1,2 and 5 asked the participants whether a B.A. or an M.A. degree in translation major or other related fields to language such as English Literature, was an essential requirement for becoming a member. Item number 15 inquired whether a good grasp of English and Persian outweigh a degree in translation and item 17 asked the participants if applicants who have majored in academic subjects other than English could be a member of translation offices, provided that their knowledge of both languages were good enough. Also, by designing items 3 and 4 , the researcher attempted to understand if people with high level of translation competence, regardless of their academic major, can be hired in translation agencies or not. The forth category investigated the central issue of entrance examination. Items 7 and 8 asked if translation agencies set any examinations for applicants or not. Items 9 and 10 asked about the format and kind of this examination. Another matter of considerable importance was translation training. The purpose for placing items 14 and 18 in the questionnaire was to find out whether translation agencies' managers cared about training the new members. It is noteworthy to mention that these items were included in the questionnaire to examine the professional process of translation agencies. Furthermore, the questionnaire 
consisted of several individual items. For instance, item 6 asked about the importance of experience which is needed for employment in translation agencies and item 12 explored the significance of computer skills and typing abilities. Items 11, 13 and 16 inquired respectively about the importance of age, gender and personality traits (such as responsibility) of the members.

In addition, to reach a clearer result, the researcher added two sections to the end of the questionnaire (see Appendix). One part consisted of two questions, the first of which asked how many years of experience were needed for working in translation offices. The second question solicited the managers' views on the gender of applicants; that is, if they considered gender differences, in their opinion which gender was more preferable. The last section requested the managers to prioritize different aspects for recruiting a member. These aspects were quite similar to the above mentioned factors concerning an academic degree, experience, knowledge and personality traits.

\subsection{Procedure}

The questionnaire was designed based on the two interviews the researcher conducted from June $10^{\text {th }}$ to June $16^{\text {th }} 2012$. The questionnaires were distributed in four cities of Iran, namely Isfahan, Tehran, Yazd and Karaj from June $25^{\text {th }}$ to July $21^{\text {st }}$ 2012.At the beginning, the researcher aimed to send the questionnaires to managers via email to make the procedure easier and faster. However, considering the fact that the number of respondents was limited and some people might have ignored their emails, the researcher decided to hand the questionnaires to the managers in person or with the help of some people. For taking the questionnaires to the agencies the researcher sought help from a number of friends who lived in these cities. This process was a little hard because some managers were hesitant and unwilling to complete the questionnaires. Also, in a few agencies the managers clearly stated that they did not like to answer the questions and therefore the questionnaires were taken to other agencies instead.

\section{Data Analysis and Results}

To investigate the participants' views about the items of the questionnaire, each individual item was analyzed separately. That is, the percentages for each scale (strongly agree, agree, disagree, strongly disagree, no opinion) were measured. The following tables show the obtained results. The items of each group are indicated in separate tables to be discussed more conveniently. Also, to reach a more general result, the values for the scales of strongly agree and agree were considered as agree and therefore they were added up. Similarly the cases of strongly disagree and disagree were regarded as one scale; disagree.

Table 2. Academic Degree in Translation Studies as a Major Recruitment Criterion

\begin{tabular}{lccccc}
\hline Items & $\begin{array}{c}\text { Strongly } \\
\text { agree }\end{array}$ & Agree & Disagree & $\begin{array}{c}\text { Strongly } \\
\text { disagree }\end{array}$ & $\begin{array}{c}\text { No } \\
\text { opinion }\end{array}$ \\
\hline $\begin{array}{l}\text { 1. One of the basic requirements for } \\
\text { becoming a member of this agency is } \\
\text { to have a B.A. degree in translation } \\
\text { studies. }\end{array}$ & $4 \%$ & $8 \%$ & $56 \%$ & $28 \%$ & $4 \%$ \\
$\begin{array}{l}\text { 2. People with an M.A. degree in } \\
\text { Translation Studies are our first } \\
\text { priority. }\end{array}$ & $8 \%$ & $20 \%$ & $52 \%$ & $20 \%$ & $0 \%$ \\
$\begin{array}{l}\text { 5. Owning an academic degree in } \\
\text { Translation studies is necessary but it } \\
\text { is not sufficient. }\end{array}$ & $32 \%$ & $44 \%$ & $12 \%$ & $8 \%$ & $4 \%$ \\
\hline
\end{tabular}

As indicated in Table 2, $84 \%$ of the managers disagreed with the idea of B.A. degree in translation studies as a basic requirement of being a member in translation agencies and only $12 \%$ of the participants shared the view that having a B.A. degree is an essential factor. Similarly, $72 \%$ of the participants did not agree with holding an M.A. degree as a top priority for employment whereas having an M.A. degree in translation studies seemed important for $28 \%$ of the managers. Also, $76 \%$ of the respondents agreed that having an academic degree in translation studies is a necessary requirement but it is not sufficient. On the contrary, $20 \%$ took issue with this idea and $4 \%$ held no opinion. 
In general the table above shows that the majority of participants believed that the academic degree is not a central qualification for membership and there must be other important considerations for working in translation agencies. Table 3 indicates the results for another aspect; translation competence.

Table 3. Professional Translation Competence as a Recruitment Criterion

\begin{tabular}{llllll}
\hline Items & $\begin{array}{l}\text { Strongly } \\
\text { agree }\end{array}$ & Agree & Disagree & $\begin{array}{l}\text { Strongly } \\
\text { disagree }\end{array}$ & $\begin{array}{l}\text { No } \\
\text { opinion }\end{array}$ \\
\hline $\begin{array}{l}\text { 3. For becoming a member, translation } \\
\text { competence is more important than the }\end{array}$ & $60 \%$ & $36 \%$ & $0 \%$ & $0 \%$ & $4 \%$ \\
academic degree in Translation Studies. & & & & & \\
$\begin{array}{l}\text { 4. University graduates of other majors or } \\
\text { subjects can work in this agency provided } \\
\text { that they have professional translation } \\
\text { competence. }\end{array}$ & $52 \%$ & $0 \%$ & $0 \%$ & $4 \%$ \\
\hline
\end{tabular}

As item 3 shows, 96\% regarded translation competence as more important than translation degree and there were not any disagreement over this issue. $96 \%$ of the managers shared the view that graduate students of other majors at university were allowed to become a member on condition that they had professional translation competence. There were no disagreements over this question. Therefore, it is quite clear that professional translation competence is regarded as more important than academic degree in translation studies and in the managers' opinion students of other academic subjects could be a member of agencies as well. Table 4 below shows the result for the category of employment examination.

Table 4. Entrance Examination as a Recruitment Criterion

\begin{tabular}{|c|c|c|c|c|c|}
\hline Items & $\begin{array}{c}\text { Strongly } \\
\text { agree }\end{array}$ & Agree & Disagree & $\begin{array}{l}\text { Strongly } \\
\text { disagree }\end{array}$ & $\begin{array}{c}\text { No } \\
\text { opinion }\end{array}$ \\
\hline $\begin{array}{l}\text { 7. For becoming a member, the applicants should } \\
\text { take part in an entrance examination. }\end{array}$ & $32 \%$ & $36 \%$ & $16 \%$ & $4 \%$ & $12 \%$ \\
\hline $\begin{array}{l}\text { 8. For membership, taking an entrance } \\
\text { examination is not necessary, rather the } \\
\text { applicants are interviewed. }\end{array}$ & $0 \%$ & $20 \%$ & $56 \%$ & $12 \%$ & $12 \%$ \\
\hline $\begin{array}{l}\text { 9. The entrance examination (if any) is a text that } \\
\text { is given to applicants for translation. }\end{array}$ & $44 \%$ & $40 \%$ & $0 \%$ & $0 \%$ & $16 \%$ \\
\hline $\begin{array}{l}\text { 10. In the entrance examination, the applicants' } \\
\text { general knowledge of language (such as grammar, } \\
\text { reading, writing,...) is evaluated. }\end{array}$ & $64 \%$ & $24 \%$ & $4 \%$ & $4 \%$ & $4 \%$ \\
\hline
\end{tabular}

As table 4.4 shows, $68 \%$ said the applicants need to take part in an entrance examination whereas $20 \%$ did not agree with this point. Also, $20 \%$ held the view that employment examination was not necessary for being a member and that the agencies hired members via interviews but $68 \%$ of the participants did not support this idea. $84 \%$ thought that the employment examination is in the form of a text that is given to applicants to translate. While $88 \%$ agreed that the exam evaluated the applicants' knowledge of general English (grammar, reading skills, etc.), $8 \%$ objected to this statement. This being so, most participants agreed with the idea of entrance examination in the form of a text which is given to applicants for translation. In other words, the applicants are hired based on their capabilities to translate texts well. Table 5 indicates the results for translation training. 
Table 5. Translation Training as a Recruitment Criterion

\begin{tabular}{lccccc}
\hline Items & $\begin{array}{c}\text { Strongly } \\
\text { agree }\end{array}$ & Agree & Disagree & $\begin{array}{c}\text { Strongly } \\
\text { disagree }\end{array}$ & $\begin{array}{c}\text { No } \\
\text { opinion }\end{array}$ \\
\hline $\begin{array}{l}\text { 14. The admitted applicants need to take a } \\
\text { course in translation training. }\end{array}$ & $0 \%$ & $32 \%$ & $48 \%$ & $4 \%$ & $16 \%$ \\
$\begin{array}{l}\text { 18. After the recruitment, the required } \\
\text { training is presented informally(they are not } \\
\text { necessarily held in the class) }\end{array}$ & $56 \%$ & $36 \%$ & $0 \%$ & $0 \%$ & $8 \%$ \\
\hline
\end{tabular}

As table 5 suggests, only $32 \%$ of the respondents thought that a translation training course is needed at the beginning for becoming a new member in translation agencies. On the other hand, $52 \%$ disagreed with translation training classes and $16 \%$ had no opinion over this issue. Additionally, $92 \%$ shared the idea that the translation training is offered to the applicants but it is not necessarily in the form of classes or courses. Generally, it is obvious that translation training courses are not considered to be very important for recruiting new members. The next part shows findings for the language competence qualification.

Table 6. Language Competence as an Important Recruitment Criterion

\begin{tabular}{lccccc}
\hline Items & $\begin{array}{c}\text { Strongly } \\
\text { agree }\end{array}$ & Agree & Disagree & $\begin{array}{c}\text { Strongly } \\
\text { disagree }\end{array}$ & $\begin{array}{c}\text { No } \\
\text { opinion }\end{array}$ \\
\hline $\begin{array}{l}\text { 15. In my opinion, a good command of } \\
\text { source and target language is more } \\
\text { important than a university degree. }\end{array}$ & $60 \%$ & $36 \%$ & $0 \%$ & $0 \%$ & $4 \%$ \\
$\begin{array}{l}\text { 17. In my opinion, translation agencies } \\
\text { can hire graduates of other university } \\
\text { majors for translating different texts. } \\
\text { (provided that they are good at both }\end{array}$ & $48 \%$ & $44 \%$ & $4 \%$ & $0 \%$ & $4 \%$ \\
languages) & & & & \\
\hline
\end{tabular}

Considering table $6,96 \%$ of the participants believed that a good command of source and target language is more important than academic degree and $92 \%$ agreed that graduate students of other fields of study could be hired if they were good at both languages. The results imply that the majority of participants believe that extensive knowledge of both source and target languages sounds more significant than academic degree in translation studies. Table 7 shows the results for items that were not clustered. That is, because these items did not have corresponding or equivalent cases in the questionnaire, the researcher decided to place all of them in one table.

Table 7. Other Probably Important Considerations for Recruitment

\begin{tabular}{lccccc}
\hline Items & $\begin{array}{c}\text { Strongly } \\
\text { agree }\end{array}$ & Agree & Disagree & $\begin{array}{c}\text { Strongly } \\
\text { disagree }\end{array}$ & $\begin{array}{c}\text { No } \\
\text { opinion }\end{array}$ \\
\hline $\begin{array}{l}\text { 6. In order to work in this agency, the } \\
\text { applicants ought to have good } \\
\text { experience in translation, otherwise } \\
\text { they will not be employed. }\end{array}$ & $32 \%$ & $56 \%$ & $12 \%$ & $0 \%$ & $0 \%$ \\
$\begin{array}{l}\text { 11. Age of the applicants is an important } \\
\text { issue for employment. }\end{array}$ & $4 \%$ & $24 \%$ & $48 \%$ & $12 \%$ & $12 \%$ \\
$\begin{array}{l}\text { 12. Knowing how to work with } \\
\text { computers and having typing skills are } \\
\text { matters of great importance for } \\
\text { membership. }\end{array}$ & $60 \%$ & $32 \%$ & $4 \%$ & $0 \%$ & $4 \%$ \\
\hline
\end{tabular}




$\begin{aligned} & \text { 13. Gender of the applicants is an } \\ & \text { consideration for }\end{aligned}$
$\begin{aligned} & \text { important } \\ & \text { membership. }\end{aligned}$

As table 7 suggests, $88 \%$ of the managers were of the same opinion that having enough experience in translation was a significant qualification for new members while $12 \%$ disagreed with this item. Regarding age, $28 \%$ thought age is an important issue in recruiting new members but $60 \%$ did not consider age to be an essential aspect. Moreover, $92 \%$ believed that the applicants ought to be good at using a computer and should have typing skills while $4 \%$ did not have such an opinion. Considering gender, whereas $16 \%$ of the managers thought that the gender of applicants is an important consideration in employment, $72 \%$ believed that gender was not a recruitment criterion. In addition, $100 \%$ of the managers believed that an applicant ought to be conscientious and responsible in order to become a member of translation agencies. Thus, by and large factors such as age and gender do not seem to have much importance for managers of translation agencies while good experience, typing skills and personality traits (such as conscientiousness) sound to be of paramount importance.

Furthermore, as stated in section 3.2, two parts were added to the questionnaires to reach a more acceptable result. The first section contained questions regarding the required years of experience and the gender of applicants. Tables 8 and 9 below show the results respectively:

Table 8. Experience Required for Membership in Translation Agencies

\begin{tabular}{lcccccc}
\hline Question & $1-4$ years & $4-8$ years & $\begin{array}{c}8-12 \\
\text { years }\end{array}$ & $\begin{array}{c}12-16 \\
\text { years }\end{array}$ & $\begin{array}{c}\text { Over } 16 \\
\text { years }\end{array}$ & $\begin{array}{c}\text { No } \\
\text { experience is } \\
\text { required }\end{array}$ \\
\hline $\begin{array}{l}\text { At least ...years of } \\
\text { experience are } \\
\text { required for } \\
\text { membership }\end{array}$ & $84 \%$ & $8 \%$ & $0 \%$ & $0 \%$ & $0 \%$ & $8 \%$ \\
\hline
\end{tabular}

As it is indicated in table $4.8,84 \%$ of the managers held the opinion that one to four years of experience are required for membership while $8 \%$ believed that four to eight years of experience are necessary for recruitment. Although the questionnaire did not contain the alternative "no experience", two managers $(8 \%)$ had provided some explanatory notes of their own next to this question that experience is not a crucial factor for membership. In questionnaire 10 , the manager had stated that "some people with no experience do a great job and it seems that preparing a good translation is a kind of talent that some have and some do not". The following table shows the results for the gender of applicants.

Table 9. Preferable Gender for the Applicants

\begin{tabular}{lccc}
\hline Question & $\begin{array}{c}\text { It is preferable to hire } \\
\text { female applicants }\end{array}$ & $\begin{array}{c}\text { It is preferable to hire } \\
\text { male applicants }\end{array}$ & $\begin{array}{c}\text { No gender } \\
\text { considerations are } \\
\text { taken into account }\end{array}$ \\
\hline In this agency,....... & $16 \%$ & $0 \%$ & $84 \%$ \\
\hline
\end{tabular}

As the table implies, $84 \%$ did not regard gender as an important factor and whereas $16 \%$ thought female applicants are preferable, none of the participants considered male applicants as better cases for membership.

Also, the last section of the questionnaire requested the managers to prioritize different aspects for recruiting a member. These factors were all investigated in the questionnaire but this section allowed the researcher to probe more deeply into the problem under focus. Table 4.10 lists the order of priorities according to the managers' views: 
Table 10. The Order of Priorities for Employing New Members in Translation Agencies

\begin{tabular}{|c|c|c|c|c|}
\hline Priority & First Priority & Second Priority & Third Priority & Fourth Priority \\
\hline & $\begin{array}{l}60 \% \text { : experience in } \\
\text { translation }\end{array}$ & $\begin{array}{l}40 \% \text { : experience } \\
\text { in translation }\end{array}$ & $\begin{array}{c}\text { 44\%: academic } \\
\text { degree }\end{array}$ & $\begin{array}{l}48 \% \text { : personality } \\
\text { traits }\end{array}$ \\
\hline Importance of & $\begin{array}{l}32 \% \text { : language } \\
\text { competence }\end{array}$ & $\begin{array}{l}40 \% \text { : language } \\
\text { competence }\end{array}$ & $\begin{array}{l}36 \% \text { : personality } \\
\text { traits }\end{array}$ & $\begin{array}{c}\text { 44\%: academic } \\
\text { degree }\end{array}$ \\
\hline $\begin{array}{l}\text { Recruitment } \\
\text { Standards }\end{array}$ & $\begin{array}{c}4 \% \text { : academic } \\
\text { degree }\end{array}$ & $\begin{array}{l}12 \% \text { : personality } \\
\text { traits }\end{array}$ & $\begin{array}{l}20 \% \text { : language } \\
\text { competence }\end{array}$ & $\begin{array}{l}\text { 8\%: language } \\
\text { competence }\end{array}$ \\
\hline $\begin{array}{l}\text { According to the } \\
\text { Managers }\end{array}$ & $\begin{array}{l}4 \% \text {; personality } \\
\text { traits }\end{array}$ & $\begin{array}{l}\text { 8\%: academic } \\
\text { degree }\end{array}$ & $\begin{array}{l}0 \% \text { : experience in } \\
\text { translation }\end{array}$ & $\begin{array}{l}0 \% \text { : experience in } \\
\text { translation }\end{array}$ \\
\hline
\end{tabular}

The results of this section show that $60 \%$ of the respondents prioritized experience over other factors while only $32 \%$ thought that language competence should be the first criterion. Besides, $4 \%$ thought academic degree in translation takes precedence over everything else and $4 \%$ rated personality traits as the first factor. On the other hand, $40 \%$ gave the second priority to language competence and experience in translation and only $12 \%$ believed that personality traits are the second crucial aspect. $44 \%$ of the participants believed that having an academic degree is the third priority and $48 \%$ rated personality traits as the fourth paramount factor for being a member of translation agencies. In general, the obtained results indicate that experience in translation is the most crucial standard while language competence is the second priority for membership. Table 4.10 also shows that academic degree in translation studies is given the third priority by most participants and personality traits take the fourth priority.

\section{Concluding Remarks}

This study aimed to examine the recruitment criteria of official translation agencies in Iran. Because of the limited number of agencies under focus in this study, the findings are more of an indication rather than a generalization.

The results of this research reveal that the majority of managers (96\%) consider translation competence as a more important criterion than an academic degree in English or Translation Studies. In addition, almost all participants (96\%) share the view that language competence is much more significant than academic degree in Translation Studies for membership. Almost all managers believe students or graduates of other academic majors could be hired as members of agencies provided that they had a good command of both the source and target languages and were competent enough to translate texts. Additionally, a large number of managers (88\%) take the view that having good experience in translation is imperative; otherwise the applicants will not be admitted. Computer and typing skills also seem to be of considerable importance for a great number of managers (92\%). All managers $(100 \%)$ place a high value on the responsibility and conscientiousness of those who apply for the occupation. However, factors like age and gender do not appear to be important to the managers. By and large, it could be claimed that professional skill and competence in translation are considered to be of much greater significance than academic degree. In other words, the findings reveal that although having an academic degree might be necessary for membership of a few agencies, it is not sufficient and one needs to improve his skills and abilities to be accepted as a member. That is, managers do not trust the people with academic qualifications without measuring their proficiency in translation. This also shows the fact that as a result of inappropriate training in universities; graduates of Translation Studies are not professionally qualified and competent in translation. Therefore, with regard to the implications of the present study, some new policies ought to be adopted by curriculum designers, professors, or translation trainers in universities or other academic institutes to modify translation training courses in such a way that a high value is placed upon translation practice. In this way, graduates in the field could be more hopeful to find a job related to their academic field and managers could hire more professional translators who are able to fulfill the market needs.

\section{References}

Defeng, L. (2000). Tailoring translation programs to social needs : a survey of professional translators. Target, 12 (1), 127-149. Defeng, L. (2003). Translator training : What translation students have to say. Meta, 47 (4), 513-531.

Defeng, L. (2007). Translation Curriculum and Pedagogy: Views of Administrators of Translation Services. Target Quarterly, 19(1), 1045-133. 
Gabr, M. (2007). A TQM approach to translator training: Balancing stakeholders' needs and responsibilities. The Interpreter and Translator Trainer, 1(1), 65-77.

Gouadec, D. (2007). Translation as a profession. Amsterdam: John Benjamins.

Jan Chan, A.L. (2009). Effectiveness of translator certification as a signaling device: views from the translator recruiters. In R. Sela-Sheffy, \& M. Shlesinger (Eds.), Identity and status in the translational professions (pp. 31-48). Amsterdam: John Benjamins.

Pym, A. (2011). Training Translators. In K. Malmkjaer \& K. Windle (Eds.), The Oxford Handbook of Translation Studies (pp. 475489). Oxford : Oxford University Press.

Samulesson- Brown, G. (2004). A practical guide for translators (4th ed.).UK : Multilingual Matters Ltd.

Samuelsson-Brown, G. (2006). Managing translation services. UK: Multilingual Matters.

Yazdanparast, M. (2012). A Study on the Courses for MA Translation Students in Iran : Are Graduate Students Welcome by the Market?. Master's thesis, University of Isfahan, Isfahan, Iran.

\section{Appendix}

\section{Dear Sir/ Madam}

Please read the following questions carefully and choose one of the options strongly agree, agree, disagree, strongly disagree, no opinion.

Thank you very much.

\begin{tabular}{|c|c|c|c|c|c|c|}
\hline $\begin{array}{l}\text { Question } \\
\text { Number }\end{array}$ & $\begin{array}{l}\text { To what extent are the following true } \\
\text { about your translation agency? }\end{array}$ & $\begin{array}{l}\text { Strongly } \\
\text { agree }\end{array}$ & agree & disagree & $\begin{array}{l}\text { Strongly } \\
\text { disagree }\end{array}$ & No opinion \\
\hline 1 & $\begin{array}{l}\text { One of the basic requirements for } \\
\text { becoming a member of this agency is to } \\
\text { have a B.A. degree in translation studies. }\end{array}$ & & & & & \\
\hline 2 & $\begin{array}{l}\text { People with an M.A. degree in Translation } \\
\text { Studies are our first priority. }\end{array}$ & & & & & \\
\hline 3 & $\begin{array}{l}\text { For becoming a member, translation } \\
\text { competence is more important than an } \\
\text { academic degree in Translation Studies. }\end{array}$ & & & & & \\
\hline 4 & $\begin{array}{l}\text { University graduates of other majors or } \\
\text { subjects can work in this agency provided } \\
\text { that they have professional translation } \\
\text { competence. }\end{array}$ & & & & & \\
\hline 5 & $\begin{array}{l}\text { Owning a degree in Translation studies is } \\
\text { necessary but it is not sufficient. }\end{array}$ & & & & & \\
\hline 6 & $\begin{array}{l}\text { In order to work in this agency, the } \\
\text { applicants ought to have good experience } \\
\text { in translation; otherwise they will not be } \\
\text { employed. }\end{array}$ & & & & & \\
\hline 7 & $\begin{array}{l}\text { For becoming a member, the applicants } \\
\text { should take part in an employment } \\
\text { examination. }\end{array}$ & & & & & \\
\hline 8 & $\begin{array}{l}\text { For membership, taking an employment } \\
\text { examination is not necessary, rather the } \\
\text { applicants are interviewed. }\end{array}$ & & & & & \\
\hline 9 & $\begin{array}{l}\text { The employment examination (if any) is a } \\
\text { text that is given to applicants for } \\
\text { translation. }\end{array}$ & & & & & \\
\hline 10 & $\begin{array}{l}\text { In the employment examination, the } \\
\text { applicants' general knowledge of } \\
\text { language (such as grammar, reading, } \\
\text { writing,...) is evaluated. }\end{array}$ & & & & & \\
\hline
\end{tabular}




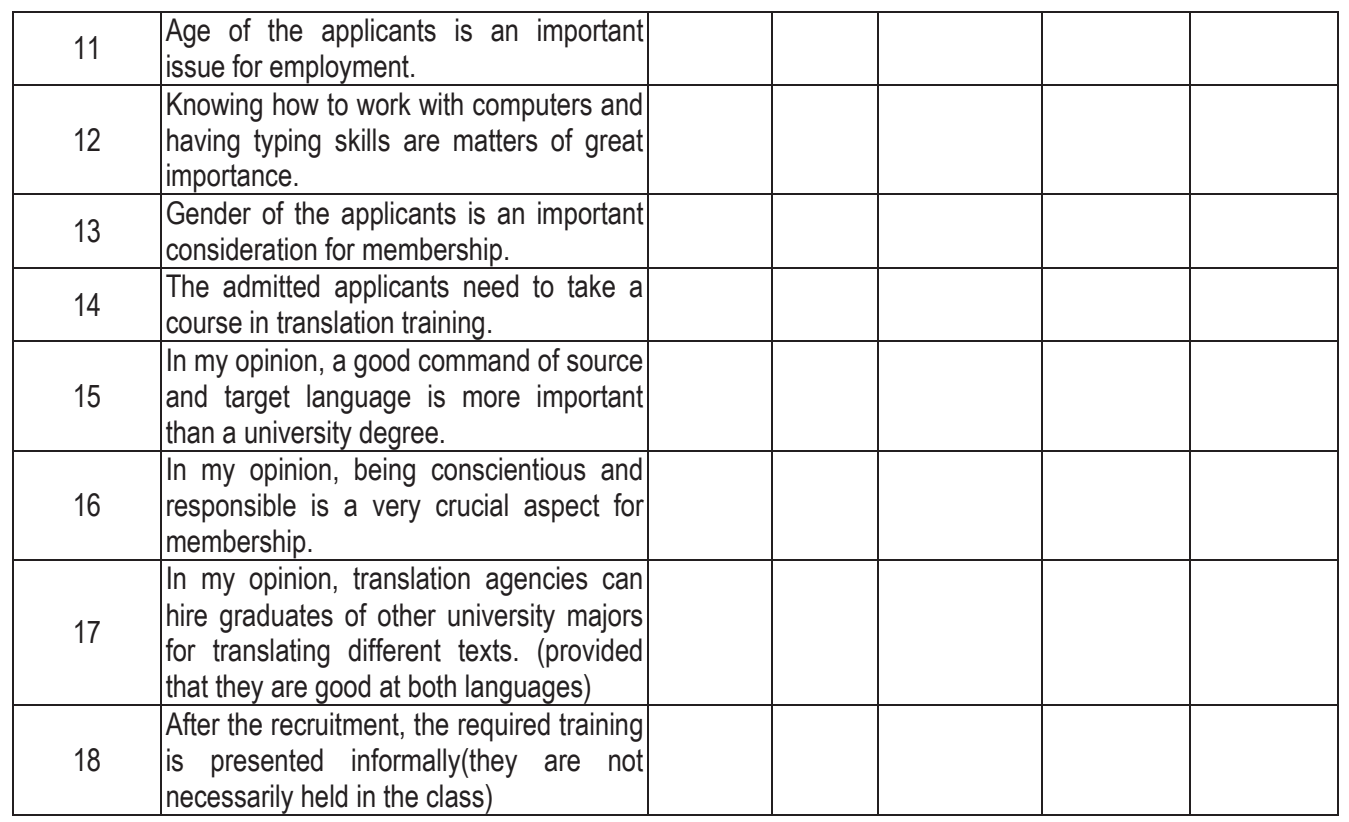


